
\title{
25 Research Square \\ Development and Performance Test of Molten Carbonate Fuel Cell Stack
}

\section{Ruiyun Zhang ( $\sim$ 378022698@qq.com )}

Huaneng Clean Energy Research Institute

Chengzhuang Lu

Huaneng Clean Energy Research Institute

Hao Li

Huaneng Clean Energy Research Institute

Jian Cheng

Huaneng Clean Energy Research Institute

Xian Zhou

Huaneng Clean Energy Research Institute

Shisen Xu

China Huaneng Group\Huaneng Clean Energy Research Institute

Guanjun Yang

Huaneng Clean Energy Research Institute

Hua Huang

Huaneng Clean Energy Research Institute

\section{Research}

Keywords: Molten Carbonate Fuel Cell,matrix, electrode, stack, performance test

Posted Date: June 26th, 2020

DOI: https://doi.org/10.21203/rs.3.rs-36670/v1

License: (c) (i) This work is licensed under a Creative Commons Attribution 4.0 International License.

Read Full License 


\section{Abstract}

In order to solve the problems of the preparation and matching characteristics of key materials in the development of large area and large power molten carbonate fuel cell(MCFC) stack, the assembly and test operation method of $10 \mathrm{~kW}$ MCFC stack is proposed. In this paper, the preparation method of matrix and electrode for large area MCFC is proposed. A $10 \mathrm{~kW}$ class MCFC power generation system with 120 cells and an effective area of $0.2 \mathrm{~m}^{2}$ for each cell is assembled and operated. In the constant voltage discharge test, the maximum output power is $16.51 \mathrm{kw}$ and the current density is greater than $95 \mathrm{~mA} / \mathrm{cm}^{2}$. In view of many experiments and analysis, an effective online evaluation method for the baking effect of MCFC electrolyte matrix is obtained, which makes the matrix, electrode and molten salt electrolyte in the molten carbonate fuel cell body form a good match, which has an important guiding significance for improving the assembly and long-term operation of MCFC battery stack. The development and performance test method of the MCFC stack in this paper will provide effective theoretical and experimental guidance for the subsequent development of the larger MCFC power generation system, which is of great significance to promote the commercial demonstration and promotion of MCFC.

\section{Introduction}

Molten carbonate fuel cell (MCFC) is a kind of power generation technology which directly converts the chemical energy of fuel into electrical energy at $650^{\circ} \mathrm{C}^{[1]}$. It has the advantages of wide fuel source, e.g. pure $\mathrm{H}_{2} \square$ coal-formed gas $\square$ natural gas and other hydrogen containing gas all could be the fuel, small floor area, less pollutant emission, high power generation efficiency, and its service life can reach more than $40000 \mathrm{~h}$. Moreover, it can participate in electrochemical reaction with air and $\mathrm{CO}_{2}$ as raw materials and the $\mathrm{CO}_{2}$ produced can be recycled and the emission of greenhouse gases is greatly reduced, which is of great practical significance for energy conservation and emission reduction and energy efficiency improvement.

MCFC has been carried out $60000 \mathrm{~h}$ of long-term demonstration operation in the United States, Japan, Germany, Italy, South Korea and other developed countries with power capacity of more than megawatts. At present, the material system of MCFC has been basically finalized, and the cost can be greatly reduced after the realization of full localization. It can take the lead in the promotion and application of commercialization in China, especially suitable for the distributed power generation system of CCHP, which has a good development prospect.

\section{Experimental}

\subsection{Preparation and characteristics of MCFC electrolyte matrix}


The electrolyte matrix is the most important part of MCFC ${ }^{[2-5]}$. The performance of matrix has a great influence on the performance of MCFC. How to make high quality matrix becomes the key of research. Generally speaking, the performance of the matrix is closely related to its porosity and average pore size. The pore distribution of the membrane after setting mainly depends on the content of the nonvolatile binder and solvent contained in the matrix before setting and the uniformity of its distribution. When the content is high, the porosity and average pore diameter of the film are large, the electrolyte immersed in the film is more, and the film resistance is small, but due to the average pore diameter is large, the risk of gas channeling between the anode and the cathode is easy to occur. When the content is low, the porosity and average pore diameter of the film are reduced, which is beneficial to gas resistance, but it reduces the electrolyte immersed in the film, and is not conducive to ionic conductivity. Therefore, a reasonable porosity and pore size distribution of the matrix is required. Generally, the porosity of the matrix is 50$70 \%$, the pore size is less than $1 \mu \mathrm{m}$, and the distribution is uniform ${ }^{[6-10]}$.

There are many methods for preparing MCFC electrolyte matrix: hot pressing, electrophoretic deposition, vacuum casting, hot and cold rolling and strip casting (casting method) and so on, the point is how to prepare high quality slurry. Large experiments show that large-scale water-soluble and environmentally friendly MCFC matrix can be prepared by using automatic casting machine, the preparation process shown in Fig. 1:

(a)Automatic Tape-Casting (b)Single matrix

(c) $400 t$ precision hot press (d)Large area matrix $(900 \mathrm{~mm} * 600 \mathrm{~mm})$

\subsection{Preparation and characteristics of MCFC electrode}

Electrode is one of the key components of fuel cell. It plays an important role in the power generation of fuel cell as follows: (1) providing a place for gas-phase and ion reaction; (2) conducting ions and electrons; (3) acting as a barrier to separate electrolyte and gas-phase reactants. As for the main characteristic of MCFC is that both anode and cathode active substances are gases, the electrochemical reaction needs a suitable solid-liquid-gas three-phase interface, so the electrode must adopt a special structure of three-phase porous diffusion electrode to facilitate the process of gas-phase mass transfer, liquid-phase mass transfer and solid-phase electronic transfer. At the same time, due to the working temperature of MCFC is about $650^{\circ} \mathrm{C}$, and the molten salt electrolyte is involved in it, the electrode material is required to have high corrosion resistance and high conductivity. Sintered nickel electrode is widely used in MCFC because of its high conductivity and good mechanical properties ${ }^{[11-15]}$. In this paper, nickel carbonyl powder is used as raw material, water is used as solvent, sodium carboxy methylcellulose (CMC) is used as binder to obtain electrode blank by casting method, and then it is sintered by walking sintering furnace. The preparation process is shown in Fig. 3:

(a)Electrode blank (b)walking sintering furnace (c)Sintered electrode(800mm $500 \mathrm{~mm}$ ) 
The results show that when the sintering speed is $10-12 \mathrm{~m} / \mathrm{h}$ and the furnace temperature is $1123 \mathrm{~K}$, the porosity of electrode is $60-80 \%$, the pore diameter is $6-10 \mu \mathrm{m}$, the thickness is $0.5-0.75 \mathrm{~mm}$, which is suitable for MCFC cathode. When the sintering speed is $8-10 \mathrm{~m} / \mathrm{h}$ and the furnace temperature is $1173 \mathrm{~K}$, the porosity of electrode is $55-70 \%$, the pore diameter is $3-5 \mu \mathrm{m}$, the thickness is $0.5-0.8 \mathrm{~mm}$ thick, which is suitable for MCFC anode.

\subsection{Assemblage and assessment of MCFC stack}

The MCFC electrolyte matrix and electrode prepared in the Lab. are used to assemble the $10 \mathrm{~kW}$ MCFC stack by the way of series connection. The series connection of the MCFC stack is 120 , and the effective area of each cell is $0.2 \mathrm{~m}^{2}$. The composition parameters of each cell are shown in Table 1 below:

Table 1 The physical parameters of matrix and

electrode in MCFC

\begin{tabular}{|lllll|}
\hline Component & Material & Area/m² & Thickness/mm & Porosity/\% \\
\hline Anode & $\mathrm{Ni}$ & 0.2 & 0.6 & 66.85 \\
\hline Cathode & $\mathrm{NiO}$ & 0.2 & 0.4 & 70.25 \\
\hline Matrix & $\mathrm{a}-\mathrm{LiAlO}_{2}$ & 0.32 & 0.6 & 55.26 \\
\hline $\begin{array}{l}\text { After the MCFC stack is assembled, a certain assembly pressure is given, and then the stack is } \\
\text { hoisted and put into the temperature rising baking furnace after the fastening bolt is tightened }\end{array}{ }^{[16-20]}$ \\
The assembly and test process of the whole MCFC stack is shown in Fig. 6 and Fig. 7.
\end{tabular}

The electrolyte needed for the matrix is $62 \mathrm{~mol}_{0} \mathrm{Li}_{2} \mathrm{CO}_{3}-38 \mathrm{~mol} \mathrm{~K}_{2} \mathrm{CO}_{3}$. The electrolyte is placed in the anode channel in advance, melts slowly with the increase of the temperature of the MCFC stack, and is immersed in the micropore under the capillary force of the diaphragm ${ }^{[21-24]}$. In order to make the heating of the MCFC stack even, the upper and lower sides of the stack are heated by electric heating wires according to the heating sequence of room temperature $-350^{\circ} \mathrm{C}-450^{\circ} \mathrm{C}-540^{\circ} \mathrm{C}-650^{\circ} \mathrm{Cand}$ a certain heating curve. Only air is introduced into the cathode to bake the diaphragm from room temperature to $540^{\circ} \mathrm{C}$, and the anode is not ventilated. When the temperature reaches $540^{\circ} \mathrm{C}$, the carbonate electrolyte melts completely, $\mathrm{H}_{2}$ is introduced into the anode of $\mathrm{MCFC}$, air and $\mathrm{CO}_{2}$ are introduced into the cathode, electrochemical reaction takes place in the MCFC, and open circuit voltage is generated; after $650^{\circ} \mathrm{C}$, electronic load discharge is introduced to test the MCFC performance.

\section{Results And Discussion}

\subsection{Performance test results of $10 \mathrm{~kW}$ MCFC battery stack}


The $10 \mathrm{~kW}$ MCFC stack assembled according to the above conditions, when the temperature reaches $650^{\circ} \mathrm{C}$, uses the $\mathrm{DC}$ feedback type electronic load to carry on the constant voltage performance test to it, the maximum open circuit voltage of the stack reaches $140 \mathrm{~V}$, the average single cell voltage is above $1.15 \mathrm{~V}$, and the discharge test is carried out at $84 \mathrm{~V}$ (average single cell voltage $0.7 \mathrm{~V}$ ), the output current is above 190A, and the discharge test is carried out. The current density reaches $95 \mathrm{~mA} / \mathrm{cm}^{2}$, the maximum output power reaches $16.51 \mathrm{~kW}$, and the output power remains stable, indicating that the MCFC stack has relatively stable performance, which shows that the prepared water-soluble matrix and electrode have good performance. In addition, since the stack is composed of 120 cells in series, it shows that under this assembly condition, the components between the cells match well, and it also shows that we have mastered the assembly and operation technology of $10 \mathrm{~kW}$ MCFC stack, and the constant voltage discharge performance is shown in Fig. 8.

\subsection{Analysis of factors influencing the performance of MCFC stack}

The performance of MCFC stack mainly depends on the electrolyte transport capacity of diaphragm, electrode and three-phase interface ${ }^{[25-28]}$. The performance of MCFC electrolyte matrix mainly depends on the first heating roasting of MCFC stack, so how to judge the baking quality of matrix is very important. After many experiments and analysis, an effective on-line evaluation method of matrix baking is obtained, which includes the following steps: (1) Before assembling the cell, record the weight of the matrix of MCFC and roughly estimate the solvent, binder, plasticizer, etc. contained in the matrix according to the formula of the matrix; (2) According to the thermogravimetry curve of the diaphragm, the heating up program of the diaphragm baking was established; (3) According to the heating procedure, the assembled cell is heated and roasted. During the heating process, a certain amount of air is introduced into the cathode and a small amount of nitrogen is introduced into the anode (in order to prevent anode oxidation); (4) During the whole roasting process, the oxygen concentration at the outlet of the cathode tail gas is monitored on-line. When the oxygen concentration changes from large to small and gradually to large, it indicates that the binder and plasticizer in the diaphragm have been completely burned, and the diaphragm forms a certain porous and flaky structure; (5) When the fuel cell reaches about 490 $500^{\circ} \mathrm{C}$, close the cathode air intake, and then the electrolyte gradually melts into the porous structure of the diaphragm; (6) When the fuel cell is stable to $600 \sim 650^{\circ} \mathrm{C}$, the electrolyte is basically full of the diaphragm. At this time, the fuel cell has preliminary power generation capacity. A certain amount of hydrogen is introduced into the anode, and a certain amount of air and carbon dioxide are introduced into the cathode. After a short activation reaction, the fuel cell can be discharged for testing ; (7) The judgment of diaphragm baking is based on the fact that there is no risk of gas channeling or leakage between the anode and cathode of the fuel cell, and the average open circuit voltage of a single cell is above 1.1 V. The whole process of on-line evaluation of the MCFC matrix baking effect is shown in Fig. 9.

After ensuring the baking effect of the matrix, by continuously optimizing the matching characteristics of the matrix electrode and molten salt electrolyte, the power generation performance of the MCFC stack can 
be effectively guaranteed, which lays a solid foundation for the long-life operation of the MCFC.

\section{Conclusions}

(1)The $10 \mathrm{~kW}$ class MCFC power generation system has been assembled and successfully operated, with the maximum output power of $16.51 \mathrm{~kW}$ and discharge current density of more than $95 \mathrm{~mA} / \mathrm{cm} 2$. The key technologies of assembly, roasting and operation management of MCFC stack have been mastered.

(2)The performance of MCFC stack mainly depends on the matching characteristics of its matrix, electrode and molten salt electrolyte. By optimizing the baking effect of the matrix and effectively immersing enough electrolyte, the good performance of the battery stack can be guaranteed.

\section{Declarations}

\section{Acknowledgements}

This work was financially supported by Integrated demonstration of coal gasification power generation system with near zero CO2 emission (2017YFB0601901).

\section{References}

1. Yi Baolian.Fuel Cell-theory technology application [M].Beijing: Chemical Industry Press,2004(in Chinese)

2. Kim B, Kim DH, Lee J, Kang SW, Lim HC (2012) The operation results of a $125 \mathrm{~kW}$ molten carbonate fuel cell system. Renew Energy 42:145e51

3. Song SA, Jang S-C, Han J, Yoon SP, Nam SW, Oh I-H et al. Enhancement of cell performance using a gadolinium strontium cobaltite coated cathode in molten carbonate fuel

4. cells (2011) J Power Sources 196:9900e5

5. Ramandi MY, Dincer I (2011) Thermodynamic performance analysis of a molten carbonate fuel cell at very high current densities. J Power Sources 96:8509e18

6. Choi HJ, Lee JJ, Hyun SH, Lim HC (2010) Phase and microstructural stability of electrolyte matrix material for molten carbonate fuel cells. Fuel Cells 4:613e8

7. Zhang R,Xu Shisen,Cheng Jian.Prepartion of electrolyte base-plate for MCFC and affecting factors therof[J].Thermal Power Generation,201140(11): 38-41(in Chinese)

8. Cheng J,Guo Liejin,Xu Shisen,et al.Preparation of a-LiAlO2 powder for MCFC by gel-solid method and its' characteristics[J].Proceedings of the CSEE,2013,33(s1): 148-152(in Chinese)

9. Lin H,Yi Baolian,Li Naichao,et al.The Study on the performance of MCFC matrix prepared by flow cast[J].Electrochemistry,1998(4): 406-413(in Chinese)

10. Cheng J,Xu Shisen,Xu Yue.Analysis of power generation technology with high-temperature fuel cells [J].Thermal Power Generation,200938(11): 7-11(in Chinese) 
11. Cheng J,Guo Liejin,Xu Shisen,et al.Key components of molten carbonate fuel cell matches and its performance diagnostic[J].Proceedings of the CSEE,2012,32(s1): 101-107(in Chinese)

12. U.S. Department of Energy Office of Fossil Energy, Morgantown Energy Technology Center, Fuel Cell Handbook,January 1994

13. Wang M,Tang Qinghu,Zhuang Zhijun.Preparation of cathode materials for molten carbonate fuel cells by aqueous tape-casting[J].Journal of Materials Science \& Engineering,2009,27(6): 928-930(in Chinese)

14. Yuh C, Hilmi A, Chen L,et al.Status of Carbonate Fuel cell Materials[M],2012

15. Antolini E.The stability of LiAlO2 powders and electrolyte matrices in molten carbonate fuel cell environment[J].Ceramics International,2013,39(4): 3463-3478

16. Choi HJ, Lee JJ, Hyun SH,et al.Fabrication and performance evaluation of electrolyte-combined aLiAlO2 matrices for molten carbonate fuel cells[J].International Journal of Hydrogen Energy,2011,36(17): 11048-11055

17. Cheng J,Guo Liejin,Xu Shisen,et al.A preparation method of electrodes for the Molten Carbonate Fuel Cell[J].Proceedings of the CSEE,2012,32(2): 80-86(in Chinese)

18. Zhang J, Zhang X,Tu M,et al (2012) Preparation of core(Ni base)-shell(Silicalite-1) catalysts and their application for alkali resistance in direct internal reforming molten carbonate fuel cell[J]. J Power Sources 198(1):14-22

19. Cheng J,Xu Shisen,Shu Kai.Test study on power generation from molten carbonate fuel cells[J].Thermal Power Generation,201039(6): 11-13(in Chinese)

20. Huang B,Zhu Xinjian,Yu qingchun,et al.kW- class molten carbonate fuel cell stack[J].Scientia Sinica Chimica,2011,41(12): 1884-1888(in Chinese)

21. Lin $\mathrm{H}, \mathrm{Zhou} \mathrm{Li}$,Ming Pingwen,et al.Influence of MCFC stacking pressure on matrix performance [J].Battery Bimonthly,200737(1): 6-8(in Chinese)

22. Li Z,Yi Baolian,Cheng Mojie,et al.Study on kW-scale molten carbonate fuel cell stacks[J].Battery Bimonthly,200232(3): 138-141(in Chinese)

23. Patil KY, Yoon SP, Han J,et al.Phase stabilities in molten Li-K carbonate of efficient matrix materials for molten carbonate fuel cells thermodynamic calculations and experimental investigations[J].Journal of Material Science,2011,46(8): 2557-2567

24. Zhou L, Lin H, Yi B,et al.Study on a new structure of the separator plate assembly for molten carbonate fuel cell(MCFC)stacks[J].Chemical Engineering Journal,2007,125(3): 187-192

25. Wang $\mathrm{H}$,Cheng Jian,Zhang Ruiyun,et al.Polarization characteristics analysis of molten carbonate fuel cell by electrochemical impedance spectrum method combining with equivalent circuit [J].Thermal Power Generation,201544(8): 95-103(in Chinese)

26. Wang P,Cheng Jian,Zhang Ruiyun,et al.Preparation and test of electrolyte film in molten carbonate fuel cell[J].Thermal Power Generation,2015,44(12): 42-45(in Chinese) 
27. Zhou L, Lin H, Yi B, Zhang H, Shao Z, Ming P, Cheng M (2006) A study on the start-up and performance of a kW-class molten carbonate fuel cell (MCFC) stack [J]. Electrochim Acta 51:5698

28. Zhou L, Lin H, Yi B, Zhang H (2007) Study on a new structure of the separator plate assembly for molten carbonate fuel cell (MCFC) stacks [J]. Chem Eng J 125:187

29. Zhou L, Lin H, Yi B (2007) Sintering behavior of porous alpha-lithium aluminate matrices in molten carbonate fuel cells at high temperature [J]. J Power Sources 164:24

\section{Figures}

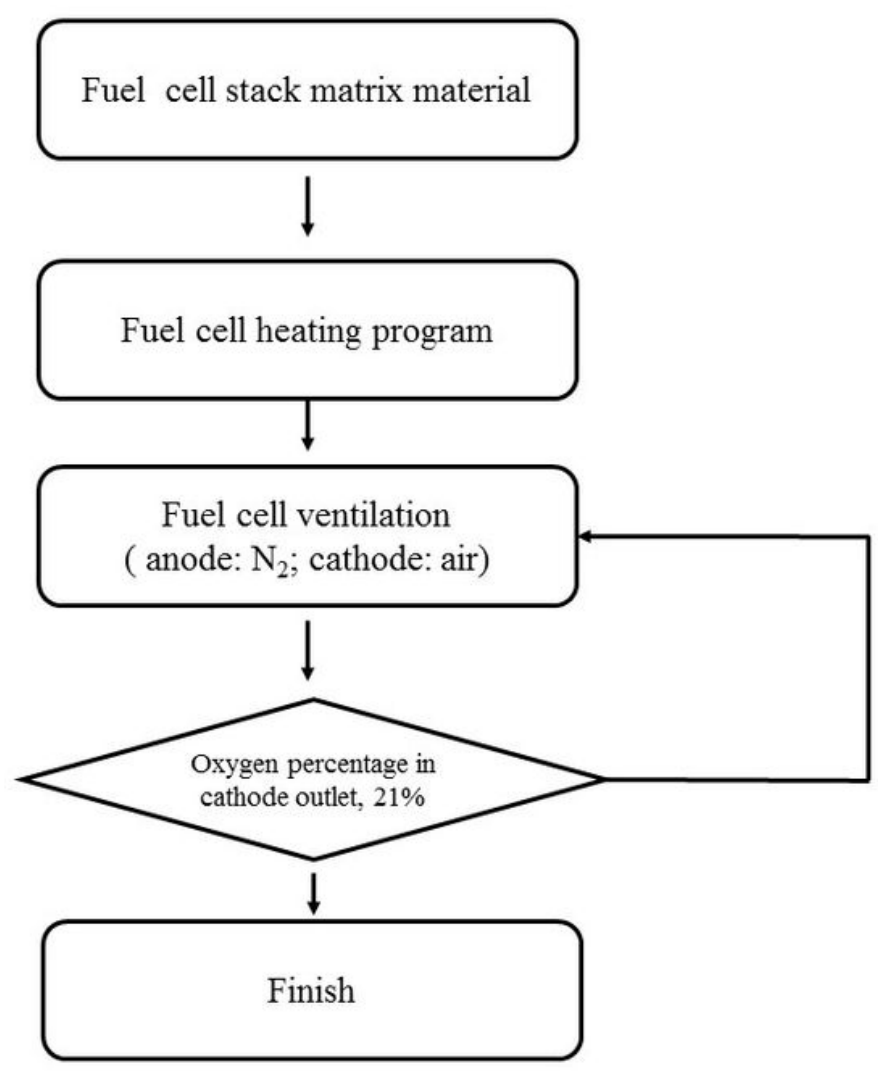

\section{Figure 1}

The whole process of on-line evaluation of the MCFC matrix baking effect 

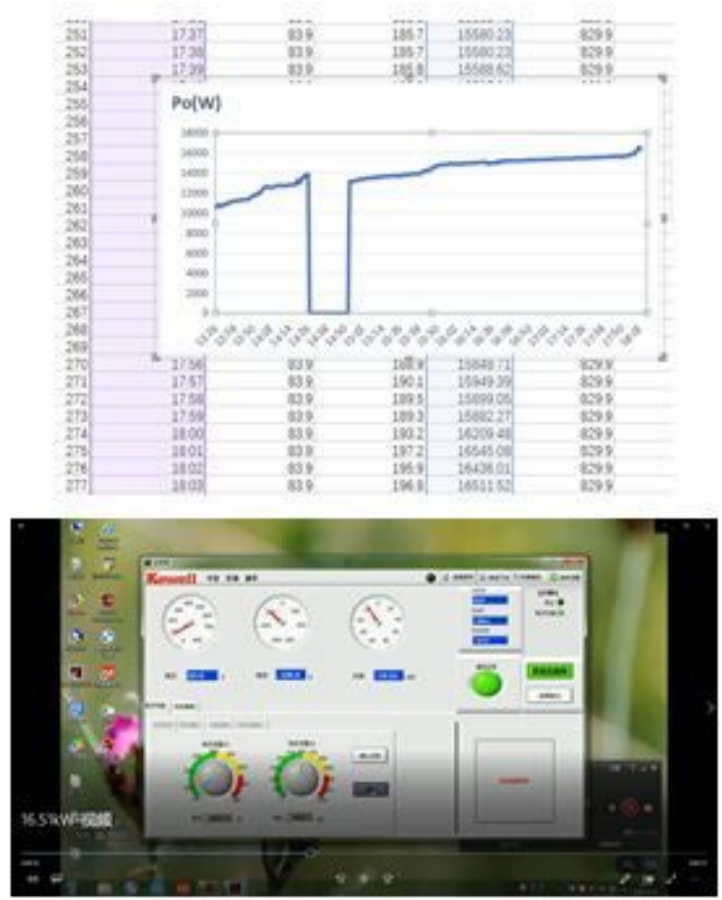

Figure 2

The constant voltage discharge performance of the MCFC stack

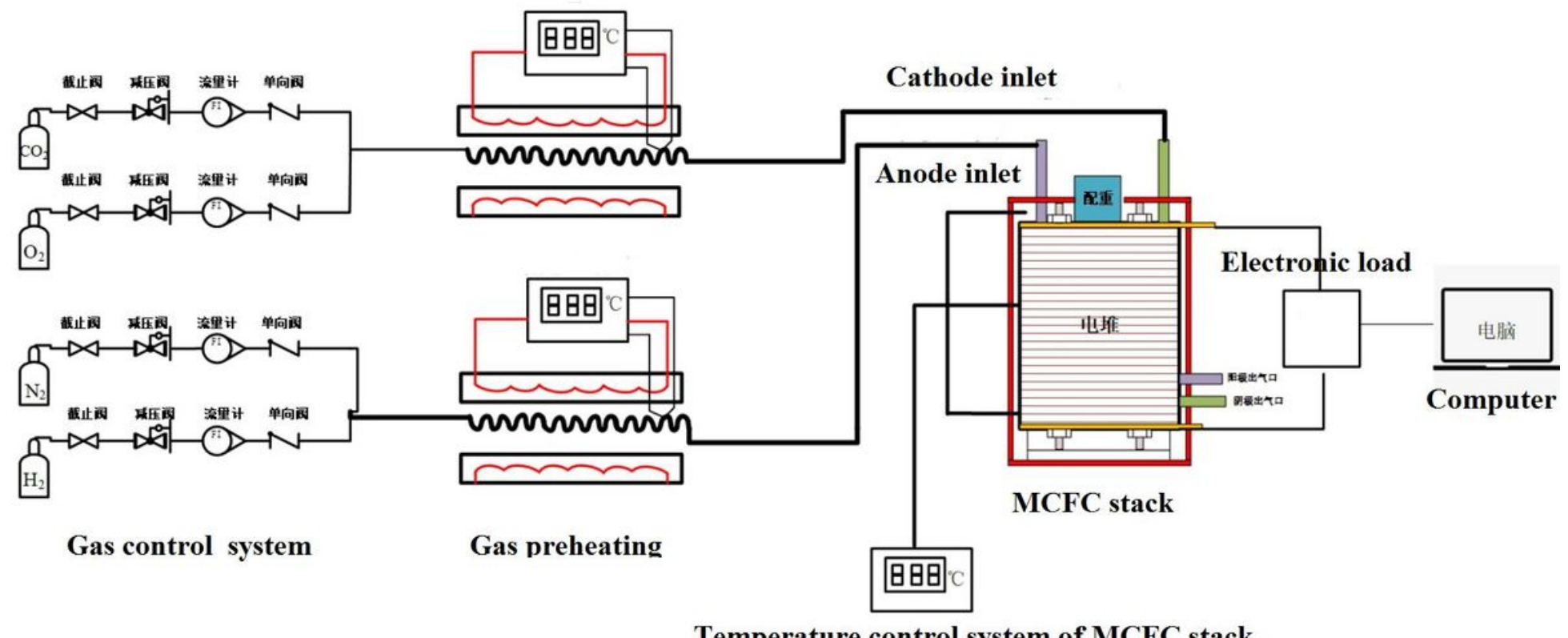

Temperature control system of MCFC stack

Figure 3

The performance test flow chart of 10kW MCFC 


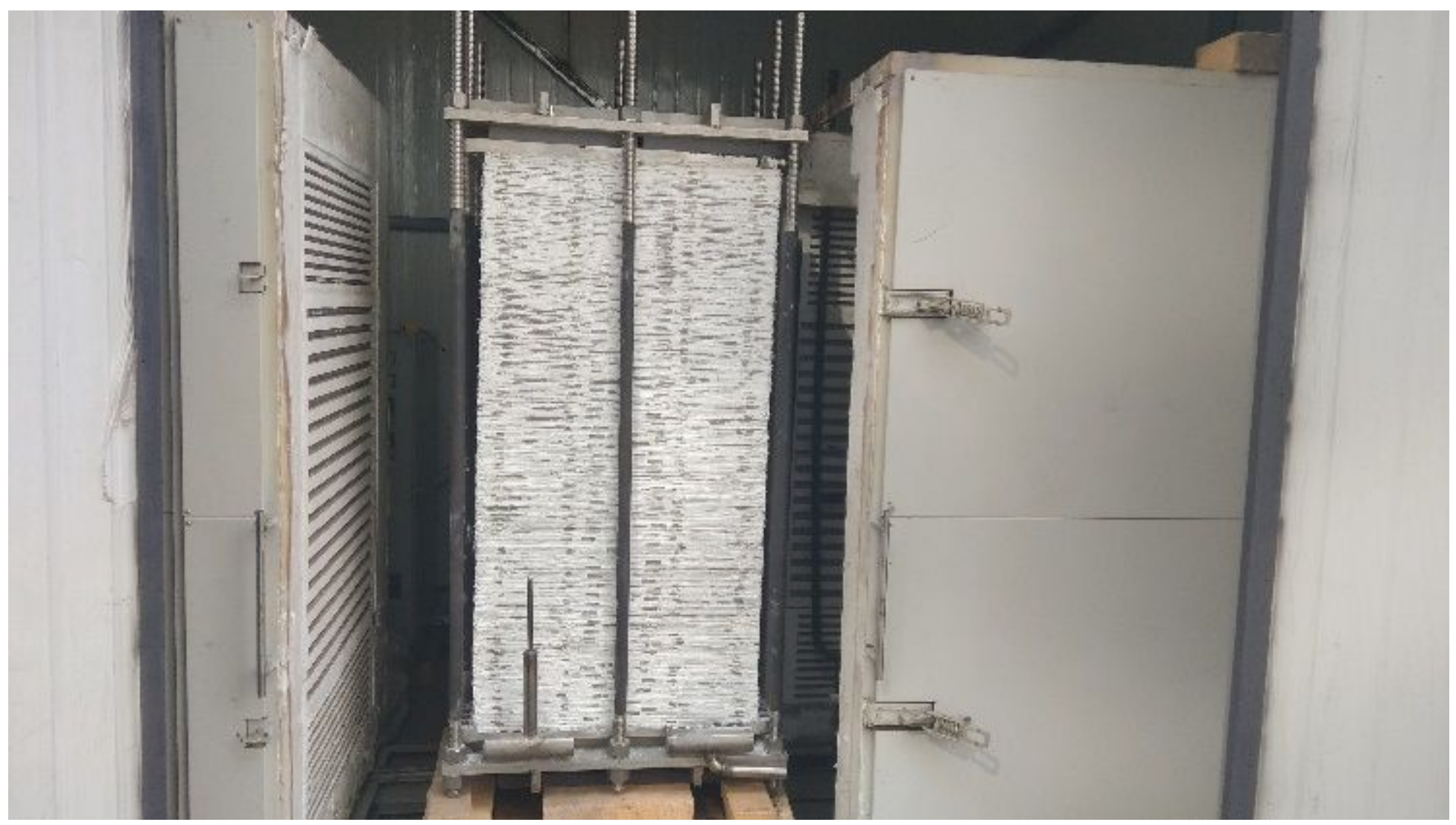

Figure 4

Assembled 10kW MCFC stack body

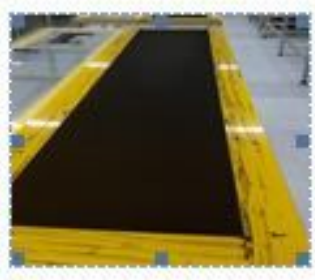

(a)Electrode blank

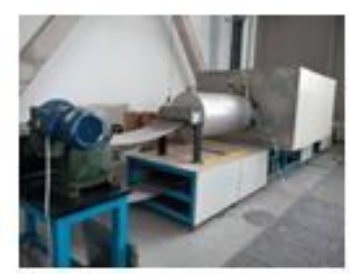

(b)walking sintering fumace

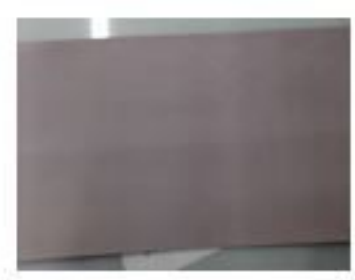

(c)Sintered electrode $(800 \mathrm{~mm} * 500 \mathrm{~mm})$

Figure 5

Large area electrode preparation process 


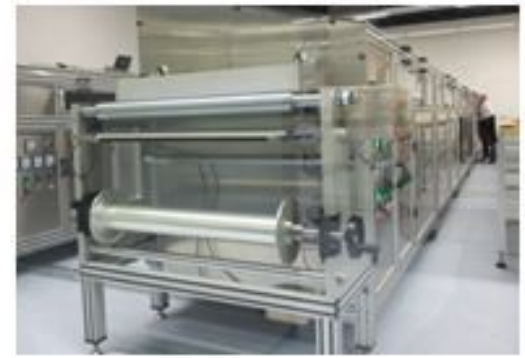

(a)Automatic Tape-Casting

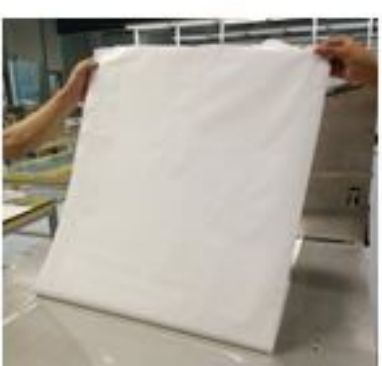

(b) Single matrix
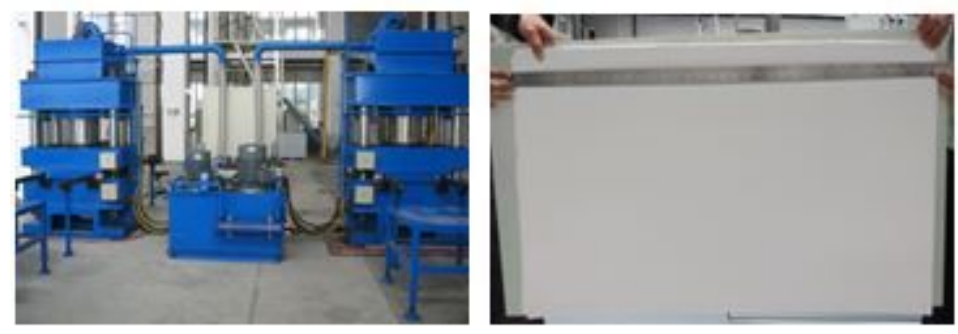

Figure 6

The tape-casting preparation process of water - based matrix

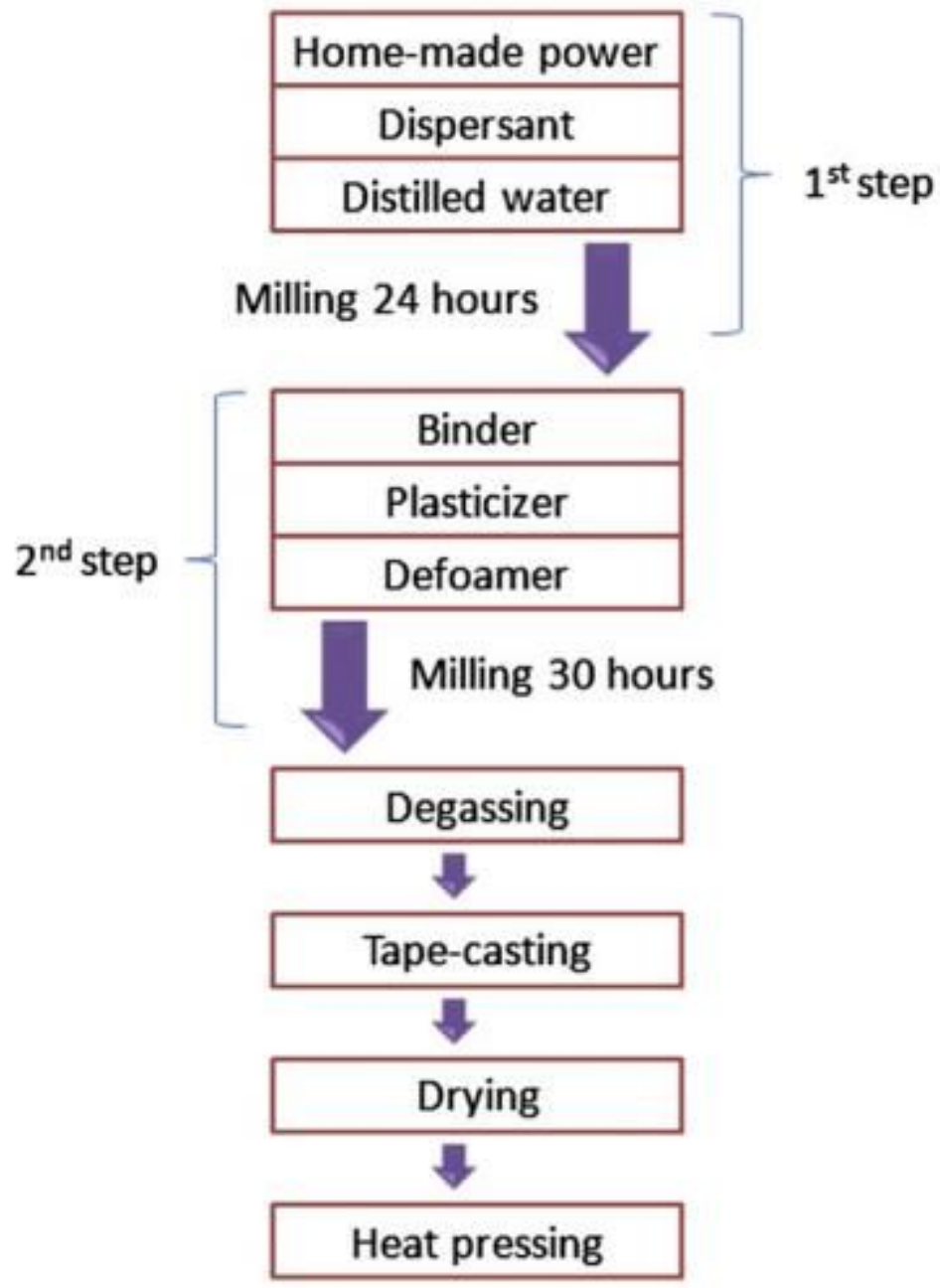

Figure 7 
Preparation of water - based matrix

Page 12/12 